\title{
O jornal Vida Operária e a instrução educacional como instrumento de inserção política
}

\author{
Luciano Everton Costa Teles*
}

Resumo: O presente texto tem como objetivo demonstrar, através do conteúdo da imprensa operária no Amazonas, como o jornal Vida Operária posicionou-se frente ao processo político eleitoral vigente na Primeira República brasileira, destacando as críticas, a proposta de ação política operária e o destaque dado à instrução (educação, no caso, saber ler e escrever, sobretudo) como instrumento de participação política.

Palavras-chave: Primeira República. Jornal Vida Operária. Instrução Educacional. Processo Político Eleitoral.

\section{Introdução}

Com a implantação da Primeira República brasileira, em quinze de novembro de 1889 , a classe operária, por meio dos seus jornais, acabou externando um processo de construção de uma efetiva participação política, no sentido de influenciar nas decisões ligadas ao campo político-econômico do país, em especial nos principais centros urbanos como São Paulo, Rio de Janeiro, Rio Grande do Sul, Bahia e outros (PÁDUA, 1985; GOMES, 1988; PETERSEN, 2001; CASTELLUCCI, 2008).

\footnotetext{
* Mestre em História Social pela Universidade Federal do Amazonas. Doutorando em História pela Universidade Federal do Rio Grande do Sul. Professor Assistente da Universidade do Estado do Amazonas. E-mail: lucianoeverton777@hotmail.com.
} 
Não obstante, a República assumiu um caráter excludente, restringindo a participação política de parcela significativa da população, incluindo aí os operários. Mulheres, menores de 21 anos e analfabetos não votavam nem se candidatavam.

Considerando os operários, a luta pela construção e pelo alargamento da participação política ocorreu de uma forma intensa. O objetivo deste artigo consiste em perceber este processo, caracterizando o sistema político da Primeira República brasileira e revelando como a imprensa operária no Amazonas, em especial o jornal Vida Operária, posicionou-se frente a ele, destacando as críticas à proposta de ação política operária e o destaque dado à instrução (educação, no caso, saber ler e escrever, sobretudo) como instrumento de participação política.

\section{A Primeira República Brasileira e a Imprensa Operária no Amazonas}

A implantação da República impactou o universo operário, o que ficou perceptível pelos artigos publicados em jornais de diversas regiões do país. No Rio de Janeiro, por exemplo, o jornal $A V$ z do Povo destacou-se pelas informações sobre a importância de se construir organizações operárias, inclusive partidos políticos operários. Em São Paulo, o jornal O Socialista seguiu também nesta esteira.

Segundo Aldrin Castellucci:

A última década do século XIX foi fortemente marcada por um clima de otimismo, expectativa e anseio de participação política gerado na classe operária brasileira em virtude da Abolição da escravidão e da Proclamação da República, levando à fundação de organizações que se autoproclamavam operárias e socialistas em vários centros urbanos do país, muitas vezes acumulando e articulando, de forma complexa e original, funções mutualistas, beneficentes, recreativas, sindicais e político-partidárias... (2008, p. 45). 
Esta posição foi fruto das profundas transformações sociais, econômicas e políticas ocorridas no Brasil a partir das duas décadas finais do século XIX, sobretudo, como destacado na citação acima, a desintegração das relações escravistas e do regime monárquico vigente.

A República implantada em quinze de novembro de 1889 envolveu esta dinâmica de transformações que vinha ocorrendo desde décadas atrás. Segundo Ângela de Castro Gomes:

O golpe vitorioso de Deodoro concluía, contudo, um processo que se iniciara décadas atrás, envolvendo questões cruciais como a abolição do trabalho escravo e a participação política dos militares, e que se materializara numa campanha com significativo grau de mobilização e organização, como o demonstra o Partido Republicano. Os interesses e a composição dos segmentos que se reuniram em nome da República são reconhecidamente diversos e complexos. A proclamação, se não é um momento de política revolucionária, é ao menos um momento de crise política que guarda uma característica fundamental dos episódios que inauguram novas experiências históricas: a instabilidade (1988, p. 19).

Após a Proclamação da República, buscou-se então definir o seu formato. Para esta definição, vários segmentos sociais procuraram participar, entre eles os operários que elaboraram e tornaram público a sua proposta de intervenção e participação política, numa clara tentativa de contribuir com o processo de formação da Primeira República brasileira.

Com efeito, os operários viram nesse processo a possibilidade da abertura de novos horizontes, sobretudo quanto à expectativa de reconhecimento social e participação política. Em Manaus, o jornal O Gutenberg (1891) $)^{1}$ externou em suas colunas este sentimento:

Esta data, na ampulheta do tempo é inapagável e, na senda da política moralizada ela é, então - sublime e toda republicana. É d'entre as letras acima flutuantes que, veio de juntarem-se dois acontecimentos na historia revolucionaria: a proclamação da República no Brasil e o aparecimento do Gutenberg na Imprensa do Amazonas. 
O dia de hoje [...] não passará despercebido para os incansáveis populares de 1889, aqueles que, prazenteiros o abrilhantavam de palmas e de risos pomposamente festivais.

A redação d'este periódico, vivamente de jubilo, comemora e assinala a proeminente data do $2^{\circ}$ aniversário da Republica brasileira (GUTENBERG, nº 1 . Manaus, 15 de novembro de 1891).

Como em outras regiões do Brasil, a implantação da República foi saudada no Amazonas como uma situação singular na história brasileira, e, como tal, vista de uma forma a assegurar mudanças significativas no universo operário. Proclamação da República e o jornal $O$ Gutenberg representavam respectivamente perspectiva de mudanças e instrumento para a defesa e difusão delas. Para isso, um ponto fundamental era a organização dos operários em associações e, principalmente em torno de um partido operário.

Em todos os Estados adiantados da União Brasileira está crescendo e solidamente firmado o Partido Operário.

Entre nós, somente o único Estado onde faltava ser organizada essa agremiação de artistas que procuram fazer valer a sua independência e a sua liberdade, acaba de ficar definitivamente criado e pronto; por conseguinte, a trabalhar em prol d'aquilo que o verdadeiro artista sempre, acima de tudo, deve procurar a sua independência.

Acaba o Partido Operário do Amazonas, de entrar no caminho do progresso e da prosperidade, ajudado, estamos, convictos d'isto por todos os artistas e operários, sem distinção de classe e nacionalidades, tendo todos em mira o engrandecimento do mesmo partido (GUTENBERG, $\mathrm{n}^{\circ}$ 19. Manaus, $1^{\circ}$ de maio de 1892$)$.

O novo regime tomou um caminho distante dos anseios e desejos dos operários, pois assumiu a República um caráter excludente em virtude de ter sido hegemônica a proposta do núcleo republicano civil e liberal paulista, em formatá-la excludente, federalista, francamente agrarista e ortodoxa em termos de política financeira (GOMES, 1988, p. 39). 
Entretanto, mesmo antes dessa hegemonia, já se podia perceber esta tendência por meio do texto produzido em 1891 a respeito dos direitos políticos.

Pelo texto de 1891 teriam direitos políticos - seriam cidadãos plenos - todos aqueles maiores de 21 anos que fossem alfabetizados. Eliminava-se o requisito da renda, mas mantinha-se o indicador social como o saber ler e escrever ao mesmo tempo em que se eximia o Estado da obrigação de dar instrução primária, o que existira no período imperial (CARVALHO, 1987, p. 45).

É possível notar que esse texto excluía um número considerável da população brasileira do exercício do voto e da candidatura, marginalizando sua participação política. Além disso, o mecanismo elaborado para assegurar os espaços formais da política nacional para as oligarquias dos estados de São Paulo e Minas Gerais - a Política dos Governadores ${ }^{2}$ - conformara estes interesses num jogo de alianças que contemplava as esferas federal, estadual e municipal.

A rotinização do regime só sobreveio no quatriênio governamental do presidente Campos Sales (1898-1902), por meio da chamada política dos governadores, ou, como preferiu aquele político, política dos estados. A partir de eficiente ingerência junto à Câmara dos Deputados, o presidente Campos Sales conseguiu promover uma reforma do Regimento Interno daquela casa legislativa, de tal sorte, que a Comissão de Verificação de Poderes passou a reconhecer todos os candidatos ao parlamento que tivessem o apoio das situações estaduais e a expurgar os demais por meio das chamadas degolas. Estava conquistada a docilidade do Legislativo e o apoio do Executivo dos Estados (CASTELLUCCI, 2008, p. 30).

A Comissão de Verificação de Poderes era o instrumento, no interior da Câmara dos Deputados, utilizado para inviabilizar as candidaturas daqueles que não estivessem em consonância com setores das oligarquias estaduais dominantes, alinhados ao poder central. 
Tal pacto - Política dos Governadores - firmado pelas elites norteou as relações políticas entre o governo central e os estados. No Amazonas, a situação não foi diferente, embora os atritos entre o poder federal e estadual fossem profundos, em virtude daquele promover uma relação marginal com este, materializada nas respostas tímidas aos solicitados planos de valorização da borracha (sobretudo no âmbito da crise econômica do produto, o que provocou cisões no interior do Partido Republicano Conservador do Amazonas) e na ausência de intervenção na política local, deixando que as facções se digladiassem pelo poder.

Nesse sentido, percebe-se que os conflitos interoligárquicos, em especial no Amazonas, ficavam confinados no estado, sem intervenções do poder central, desde que não interferissem na política mais ampla, nacional. Cabe destacar que esses conflitos eram movidos por interesses particulares e se expressaram "[...] na dualidade do Legislativo e pela violação das leis que regiam o processo eleitoral". Em 1912, por exemplo, “[...] realizaram-se eleições para a Assembleia, havendo duplicata de apurações e reconhecimentos" (SANTOS, 2001, p. 53).

Com efeito, o caráter privado, as relações de mando, o apadrinhamento e a troca de favores não eram exclusivos do cenário político amazonense, mas faziam parte da dinâmica política das principais capitais brasileiras da Primeira República.

Esse ainda era o contexto dos anos vinte. Nesses anos, o jornal Vida Operária materializou os conflitos e as características da política local por meio das críticas elaboradas contra o chamado "desvirtuamento" do regime republicano, ou seja, os conflitos políticos entre as facções pelo poder, a utilização das instituições a serviço de interesses particulares, o uso do erário público para deleites pessoais e outros. Os interesses particulares em jogo, que se sobrepunham aos coletivos, eram tidos como elementos contributivos da situação de marginalização e desamparo vivido pela classe operária local.

Os entrechoques políticos, que seguramente já há quase um mês, vem constituindo a principal ordem do dia aqui em Manaus ou para melhor dizer, em todo o Amazonas 
e no país inteiro perante os verdadeiros responsáveis pelo destino da nossa terra, não passam os mesmos de uma peça verdadeiramente cômica no cenário amazonense; cuja paixão política de uns e os interesses inconfessáveis de outros, só nos pode é trazer o descrédito como habitantes que somos desse tão opulento e quão infeliz Estado.

Em tudo isso o que vemos?

$$
[\ldots]
$$

É mais do que a negação da lealdade e da pureza do regime das nossas instituições concretizadas no interesse do próprio eu; do que o resultado do bem estar deste Estado e da sua própria coletividade, na verdadeira senda do seu pleno evoluir (VIDA OPERÁRIA, no 16. Manaus, 30 de maio de 1920).

Cabe destacar que o jornal Vida Operária apresentou-se no cenário urbano amazonense em 1920, ou seja, 29 anos depois do primeiro jornal direcionado à classe operária citado anteriormente, O Gutenberg. Porém, percebe-se, pela leitura de ambos os jornais e outros localizados entre 1891 e 1928, ${ }^{3}$ que havia uma luta constante para viabilizar um Partido Operário no Amazonas. Mesmo em 1920, pelas colunas do jornal Vida Operária, buscava-se fundar um Partido Operário "novamente", o que deixa claro o movimento de avanços e recuos neste processo.

Enfim, a condução do regime republicano realizada pelos grupos oligárquicos e a consequente exclusão política e social existentes contribuíram de forma incisiva para que o operariado realizasse uma série de contraposições. Dessa forma, algumas respostas foram elaboradas pelos operários para combater a situação política e social vivida neste momento, dentre elas, a participação política dentro do sistema político vigente na Primeira República. 


\section{O jornal Vida Operária na arena jornalística amazonense: contexto e características}

No decorrer do século XIX, em especial nas duas últimas décadas, ocorreu um processo de intensificação da exploração e ( exportação da borracha na Amazônia para os principais centros industriais, E.U.A. e Inglaterra, que a utilizavam como matéria-prima para a produção de bens industriais e de consumo.

Esse produto extraído de uma árvore, chamada de seringueira, ganhou o mercado mundial após a descoberta, por meio do estudo de suas propriedades realizado por La Charles Marie de La Condamine e François Fresneau, de suas potencialidades para o processo de produção industrial, em especial para a produção de sapatos, mangueiras, correia, pneus e outros (SANTOS, 1980).

Esse contexto permitiu que a Amazônia fosse incorporada ao mercado mundial, tornando o Amazonas e sua capital, Manaus, centro comercial do produto. ${ }^{4}$ Este fato impactou a cidade que sofreu transformações de duas ordens: de infraestrutura e de crescimento populacional.

Com relação a infraestrutura, destacam-se dois elementos. $\mathrm{O}$ primeiro liga-se à existência de casas aviadoras. Estes estabelecimentos tinham a função de financiar e comercializar a borracha, decidindo inclusive quando e a quem vender este produto. Além disso, assumiam múltiplas funções, negociando com as casas importadoras as mercadorias que seriam passadas para o negociante do vilarejo, o regatão, o seringalista e, por fim, o seringueiro, providenciando o transporte e a distribuição dos retirantes que se deslocavam do nordeste para os seringais, atuando como representante legal e financeiro de seus clientes mais ricos que residiam no interior e, por fim, realizando a abertura de novos seringais (WEINSTEIN, 1993, p. 33-34).

O papel desempenhado por esses estabelecimentos comerciais foi o de financiar e comercializar a borracha na região, fazendo chegar os implementos necessários à organização e funcionamento da vida econômica dos seringais, bem como 
recebendo deles, no final do período de extração, as remessas de borracha que, posteriormente seriam exportadas para a Europa e Estados Unidos (PINHEIRO, 1999, p. 37).

O segundo elemento refere-se ao capital estrangeiro que passou a atuar na região com o objetivo de viabilizar a exploração do produto, contribuindo dessa forma não só para reconstrução/ revitalização da cadeia comercial desenvolvida na Amazônia, ancorada no sistema de aviamento ${ }^{5}$, como também para a construção, na cidade de Manaus, de uma infraestrutura que possibilitasse o escoamento do produto.

Portanto, escoar o produto pela referida cidade era fundamental, uma vez que a produção da borracha se dava fora do espaço urbano (nos seringais). Nesse sentido, era importante criar uma gama de atividades econômicas ligadas à circulação, ao consumo e a serviços (transportes, limpeza pública, água, luz, esgoto). Essas atividades foram viabilizadas pelo capital estrangeiro, sobretudo o inglês, que se tornou o maior responsável pela execução dos grandes projetos de reforma da cidade (DIAS, 1999, p. 50).

Conforme Maria Luiza Ugarte Pinheiro, praticamente todos os serviços urbanos, por concessão, estavam nas mãos de firmas inglesas que passaram a agenciar melhoramentos ou mesmo criar serviços até então inexistentes na cidade. Empresas como a Manáos Markets, Manáos Tramways and Light, Manáos Improviments, Manáos Harbour, Amazon Engineering, Amazon Telegraph, Booth Line e Amazon River, passaram a manter relações cotidianas com a população local (1999, p. 42).

Com efeito, diversas atividades, em grande medida moldadas pela posição econômica assumida pela cidade, foram desenvolvidas. Além das firmas estrangeiras que atuavam na administração dos serviços urbanos (porto, transporte, energia, abastecimento de água etc.), ocorreu uma ampliação significativa da praça comercial. Diversos estabelecimentos comerciais passaram a oferecer uma variedade de produtos nacionais e importados, assim como uma ampla gama de serviços (hotéis, restaurantes, botequins etc.). Também surgiram marcenarias, sapatarias, alfaiatarias, fábricas de 
tecido, fábricas de roupas, fábricas de cestas e vassouras, funilarias, tabacarias, fábricas de panificação, fábrica de cerveja e gelo, fábrica de sabão e outros (COSTA, 1997, p. 53).

O mercado de trabalho na cidade de Manaus desenvolveu-se tendo como alicerces as atividades de circulação e consumo, havendo a atuação, em pequena escala, de oficinas/fábricas específicas.

Cabe lembrar que esse contexto promoveu a imigração/ migração. Um número significativo de pessoas deslocou-se para a capital do Amazonas em busca de trabalho. Segundo Edineia Mascarenhas Dias:

É no decorrer desse processo [de expansão econômica] que Manaus passa a vivenciar a ampliação e remodelação de seu espaço, assim como o aumento de sua população. Se em 1852 a cidade contava com uma população de 8.500 habitantes, em 1890 já tem sua população ampliada para 50.300, sendo o processo migratório o principal responsável por este crescimento populacional. O centro urbano se constitui como pólo de atração de gente das mais diversas nacionalidades: ingleses, alemãs, portugueses, espanhóis, italianos, franceses, deslocam-se para cá, com também imigrantes de vários estados do país (1999, p. 38).

Esse contingente trouxe consigo experiências e ideias que se materializaram nos diversos jornais produzidos e distribuídos na cidade entre 1880-1930. Essas folhas impressas retratavam as questões ligadas à ordem pública, à exportação da borracha, ao poder publico estadual, aos conflitos sociais etc.

Eram variados e assumiam a forma de pasquins, cujo foco era a sátira social, de imprensa estudantil que discutia tanto questões literárias e científicas quanto questões políticas de âmbito local e nacional, de "polyanthéas", espécie de impresso produzido em homenagem a governadores, artistas e instituições políticas e sociais, de "grande imprensa" composta pelo O Amazonas, Jornal do Comércio, Diário de Notícias, Correio do Norte, Gazeta da Tarde e de jornais de cunho operário que criticavam a ordem política, econômica, social e cultural vigente. 
Foi nesse contexto, em especial na década de vinte, que surgiu o jornal Vida Operária. Foram publicados vinte e seis números, sendo o primeiro em oito de fevereiro de 1920 e o último em 26 de setembro do mesmo ano. Era de publicação semanal, vendido avulso por $\$ 200$ (duzentos réis) e por assinaturas anuais ao preço de $10 \$ 000$, semestrais ao preço de $6 \$ 000$ e trimestrais ao preço de $3 \$ 500$. Tinha grande formato, de $30 \times 43 \mathrm{~cm}$, quatro páginas e quatro colunas.

Os responsáveis por sua produção não pertenciam propriamente à classe operária, mas aos segmentos médios urbanos que se ampliaram no bojo das transformações econômicas e sociais vivenciadas a partir da exportação da borracha. O jornal tinha como diretor o professor Elesbão do Nascimento Luz e como redatores o poeta Hemetério Cabrinha e o funcionário da Delegacia Fiscal Paulino Carvalho. Como gerente estava Anacleto Reis, que segundo Maria Luiza Ugarte Pinheiro (1999) era uma destacada liderança dos estivadores manauaras e, como auxiliar, Jorge Benedito Ferreira.

Além desses, nomes como Guilherme de Oliveira, Manoel Sérvulo, Cursino Gama, Nicodemos Pacheco, Oswaldo Mário, Flávio Remar, J. Pimenta e outros apareceram assinando artigos, como demonstra o quadro a seguir:

\section{Quadro 1 - Colaboradores com matérias assinadas}

\begin{tabular}{|c|c|}
\hline Autores & Artigos \\
\hline Oswaldo Mário & Como Surgimos no 01. \\
\hline Flávio Remar & Operariado $n^{\circ} 02$; A Carestia da Vida $n^{\circ} 03$. \\
\hline Guilherme de Oliveira & Aurora Promissora n ${ }^{\circ}$ 01; Outro Rumo no 06. \\
\hline João do Monte & Colaboração no 02 ; A Postos n ${ }^{\circ} 04$. \\
\hline Santos Filho & Aproxima-se $\mathrm{n}^{\circ} 04$ \\
\hline Manoel Sérvulo & Palavras Simples n ${ }^{\circ} 06$. \\
\hline Cursino Gama & O Momento n ${ }^{\circ} 09$ \\
\hline
\end{tabular}


O jornal vida operária e a instrução educacional...

\begin{tabular}{|c|c|}
\hline Salustino Liberato & Não se Iludam no 12 ;União e Coragem no 16. \\
\hline Hemetério Cabrinha & Está na Hora no 13. \\
\hline Elesbão Luz & Sem Comentários no 13. \\
\hline Rita da Conceição Alves & O Dia do Trabalho no 14 e no 15. \\
\hline Arnaldo de Barcellos & Reportagens Oportunas n ${ }^{\circ} 16$. \\
\hline Maia Filho & $\begin{array}{l}\text { Operariado Amazonense e as Demais Classes } \\
\text { Trabalhadoras do Amazonas } n^{\circ} 17 .\end{array}$ \\
\hline J. Pimenta & Finanças da Vida Operária no 18. \\
\hline Venicius & $\begin{array}{l}\text { O Futuro Governo e as Demais Forças Vivas } \\
\text { do Estado n }{ }^{\circ} 19 .\end{array}$ \\
\hline Nicodemos Pacheco & Bilhete aos Reacionários no 20. \\
\hline Fulton & $\begin{array}{l}\text { O Dia } 14 \text { de Julho e a Eleição Governamental } \\
\text { do Amazonas n }{ }^{\circ} 21 .\end{array}$ \\
\hline Benjamin de Araújo Lima & Aos Operários do Amazonas no 23. \\
\hline Plínio & $\begin{array}{l}\text { O Sr. Camilo Prates em Luta Contra o } \\
\text { Operariado Nacional no } 23 \text {. }\end{array}$ \\
\hline Mauro Santos & Amor e Trabalho n ${ }^{\circ} 25$. $^{2}$ \\
\hline Cleomenes Honório Dias & O Que é o Operariado no 26. \\
\hline
\end{tabular}

Fonte: Jornal Vida Operária - Acervo do Laboratório de História da Imprensa do Amazonas (LHIA/UFAM).

No cenário político amazonense, as atuações de Nicodemos Pacheco, Elesbão Luz, Anacleto Reis e Cursino Gama foram constantes ao longo das duas primeiras décadas do século XX. Só para citar um exemplo representativo: em 1919, ocorreu uma greve geral a favor da jornada de oito horas de trabalho, alvo de manifestações nacionais. Em Manaus foi formado um Comitê de Operários Amazonenses para conduzir a greve. Esse Comitê era composto pelos senhores acima citados (o presidente desse Comitê era Nicodemos Pacheco). 
Como resultado desse movimento, a greve foi reprimida e o Comitê expulso do seu local de funcionamento e, consequentemente, extinto. Não obstante, o grupo que havia formado o Comitê não deixou de atuar em busca de melhorias nas condições de trabalho e vida da classe operária, como demonstra a sua presença na elaboração, produção e difusão do jornal Vida Operária e, após o desaparecimento deste, na produção do jornal "comemorativo" denominado $1^{\circ}$ de maio (1928), cujo diretor foi Cursino Gama.

Era prática do grupo de sustentação do jornal Vida Operária a transcrição de artigos e informações de jornais que circulavam em outras regiões do país. Este fato aponta para a existência de uma articulação de ideias e, longe de atuar de forma isolada na região, os articulistas estabeleciam contato com lideranças operárias de envergadura nacional. As transcrições presentes no jornal estão relacionadas no quadro a seguir:

\section{Quadro 2 - Matérias reproduzidas de outros jornais}

\begin{tabular}{|c|c|}
\hline Artigo & Jornal de onde foi extraído \\
\hline Política Operária & $\begin{array}{c}\text { A Razão do Rio de Janeiro. } \\
\text { Escrito por Mariano Garcia }\end{array}$ \\
\hline $\begin{array}{c}\text { O Que Dizem Todos } \\
\text { os Médicos Eminentes } \\
\text { (sobre o álcool) }\end{array}$ & $\begin{array}{c}\text { Relatório Inglês } \\
\text { (não há maiores informações) }\end{array}$ \\
\hline Para o Sindicatos Camaradas & Hora Social de Recife \\
\hline $\begin{array}{c}\text { O Sindicato Como Escola } \\
\text { de Energia }\end{array}$ & Jornal do Povo do Pará \\
\hline A Internacional & Hora Social de Recife \\
\hline Hino & Gráfico do Rio de Janeiro \\
\hline Ato de Fé do Operariado de Janeiro \\
\hline O Rico e o Lázaro & Baptista Amazonense \\
\hline
\end{tabular}

Fonte: Jornal Vida Operária - Acervo do Laboratório de História da Imprensa do Amazonas (LHIA/UFAM). 
Há também informações sobre a luta operária em outros países como Espanha, Portugal, França, Alemanha, Argentina, só para citar alguns exemplos. Estas informações aparecem nos primeiros números do jornal nas colunas intituladas O Que Há La Por Fora e Notícias Interessantes. Essas colunas desapareceram nos títulos posteriores.

O jornal era distribuído em associações - dentre as quais a União Operária Nacional, o Centro Operário Nacional, a Associação de Classe das Quatro Artes da Construção Civil, a Sociedade Beneficente União dos Foguistas, o Sindicato dos Estivadores, a Artes Gráficas, a União dos Moços e Marinheiros, a União de Classe dos Pedreiros, o Sindicato dos Cigarreiros, a Associação dos Construtores Civis e por fim a Coligação dos Oficiais da Marinha Mercante - Colégios, Institutos, bares e botequins.

A distribuição em associações operárias acabou por revelar a articulação do jornal no sentido de constituir uma rede, que ele procurava representar e, através da qual se sustentar social, política e financeiramente.

Os artigos e as notícias eram direcionados de um lado ao caráter opressor e explorador do capitalismo e de outro à necessidade de uma ação operária para promoção de mudanças sociais. Consoante Luciano Teles:

Nas duas primeiras páginas eram distribuídos os artigos e as notícias. Ao analisar a distribuição de ambos se percebe a existência de dois eixos principais no discurso do jornal. O primeiro está ligado à elaboração de críticas ao sistema capitalista e sua atuação exploradora e opressora sobre o operário. O segundo está associado à orientação para uma determinada ação operária no sentido de se obter uma mudança social.

Os desdobramentos que surgem a partir daí trazem como questões a importância de um veículo de comunicação para a discussão e difusão de idéias, as desigualdades sociais presentes no mundo moderno, a situação política do operariado amazonense, a ação operária a ser seguida, a organização dos trabalhadores em associações, a fundação de um partido operário, a importância do processo político-eleitoral e 
denúncias sobre questões do trabalho (acidentes de trabalho, demissões arbitrárias, multas e penalidades) e da vida (carestia dos gêneros de primeira necessidade, alcoolismo, jogatina e outros). (2011, p. 614-615).

O jornal incorporava em suas páginas questões referentes ao mundo do trabalho no Amazonas, particularmente o que brotava do universo das fábricas e das atividades ligadas ao comércio. Criticando, denunciando e propondo ações políticas, o jornal Vida Operária buscou atuar como instrumento de mobilização, conscientização e luta direcionado à classe operária. ${ }^{6}$

Ao que tudo indica, em especial pelos contatos estabelecidos com jornais e lideranças de outros centros urbanos do país, o jornal em tela assumiu uma postura socialista reformista, tendo como base a condenação da greve (vista como contraproducente) em favor das alianças e negociações com as autoridades políticas e da defesa da formação de Tribunais de Arbitragem como fóruns especiais para a solução dos conflitos entre operários e patrões.

Em suas páginas, o jornal acenava para uma atuação dentro da ordem republicana e do sistema político vigente. No seu primeiro número, essa atuação é explicitada:

\begin{abstract}
Assim sendo, a Vida Operária, lança-se hoje à luz, como defesa exclusiva do operariado desta terra maravilhosa, pronta para defender, dentro dos limites da ordem, o interesse de uma classe esquecida e vilipendiada pelos que nada produzem, a não ser a brutalidade espantosa de aumentar o capital (VIDA OPERÁRIA, nº 1. Manaus, 08 de fevereiro de 1920).
\end{abstract}

"Dentro dos limites da ordem", o jornal apresentou uma proposta de ação política operária. Essa proposta consistia na fundação de associações operárias ligadas a um centro federativo (cada estado da federação teria o seu) que se ligaria à confederação do trabalho, cuja sede seria na capital federal. O partido operário estaria ligado ao centro federativo e teria âmbito nacional. 
O objetivo era articular os operários em associações ligadas a um centro que por sua vez estaria articulado com o partido operário que se empenharia em lançar nomes para participar do processo político-eleitoral a fim de eleger representantes que atuariam no sentido de realizar, via legislação, as reformas sociais.

\begin{abstract}
E uma vez que o nosso operariado trabalhem em suas sociedades, e estabelecendo entre os seus associados várias conferencias neste sentido e lendo ao mesmo tempo os mais necessários tópicos da Constituição brasileira, e, sobre tudo na parte que se refere aos direitos civis e políticos do cidadão; creio ser mais que o bastante, para que cada associado se compenetrem dos seus principais direitos e deveres. E uma vez se trabalhando com esse intuito, tempo virá que quando se tratar de qualquer renovação para Câmara ou para o Senado da República, os companheiros serão, não enxergados por um óculo, mas sim reivindicados nos seus direitos representativos (VIDA OPERÁRIA, no 16. Manaus, 30 de maio de 1920).
\end{abstract}

O jornal publicou outro artigo, por conta de problemas vivenciados no decorrer do pleito governamental ${ }^{7}$, realizado em 14 de julho de 1920, que muito bem expressou a proposta de participação política defendida.

E ao concluir estas desalinhadas linhas, companheiros, o que só nos resta fazer apesar de todos os dissabores, é nos arregimentarmos no grande Partido Operário Socialista Amazonense; procurando difundir a instrução entre as classes; e de entre nós elegermos os nossos candidatos (por nos ser facultado esse mesmo direito); quer perante o Congresso do Estado como do Município... (VIDA OPERÁRIA, no 21. Manaus, 25 de julho de 1920).

Nesta construção de "cidadania operária", a associação e o partido político eram postos em relevo. Quanto ao terceiro elemento da luta operária, o jornal, este assumia a função de atuar no 
sentido de difundir a proposta, procurando conscientizar e mobilizar a classe operária para tal ação política e a instrução era o instrumento de inserção política.

\section{A instrução educacional como instrumento de inserção política}

No jornal Vida Operária, a importância da instrução foi destacada em dois sentidos: como geradora de conquistas intelectuais, morais, sociais e econômicas e como instrumento para garantir a inserção dos operários no sistema político vigente.

Com relação ao primeiro sentido, a instrução era encarada como elemento necessário ao "desenvolvimento coletivo" e "engrandecimento" de um país.

Também um outro ponto que devemos ter demasiadamente em vista, é a parte que diz respeito a generalização por demais intensificadora do ensino instrutivo no seio das classes proletárias.

É esta portanto, uma das ideias que devem ser preconizadas dentro das leis sociais do nosso operariado...

Pois, como todos nós sabemos; a instrução é a grandeza, a alma e a vida de um povo, e o grande progresso de uma Nação.

Procuremos, por tanto, instruirmo-nos, caros companheiros, visto como tão somente devido a instrução, foi que a outrora grande Alemanha; bem como a Bélgica, a Itália, a França, a Inglaterra e os Estados Unidos da América do Norte, se constituíram os principais Países do mundo!

$\mathrm{E}$ o que foi que deu lugar a tudo isto?

Respondo-vos.

Foram os diversos inventos das variadas industriais, entrando como parte ativa, o conhecimento da matemática, da física e da química; verdadeiras forças motoras, que em auxílios dos seus trabalhos de arte, lhes foram dado a executar. 
O jornal vida operária e a instrução educacional...

Eis aí, portanto, como foram acumulados nos vários países que ora me refiro, esses grandes capitais de operários (VIDA OPERÁRIA, no 3. Manaus, 24 de fevereiro de 1920).

Percebe-se que o jornal apontou a instrução como base @ necessária para a realização de avanços tecnológicos importantes para o desenvolvimento econômico e material de uma nação. Nesse sentido, a apropriação de conhecimentos era vista como fundamental para fomentar esse processo, pois seria aplicado na produção de tecnologias essenciais para a produção industrial. Cabe destacar que os avanços não se dariam somente neste campo como facilmente pode se levar a crer. Pelo contrário, outros elementos como a moral, o social e o intelecto seriam contemplados, segundo o jornal.

Com efeito, na perspectiva do intelecto, o saber necessário para o desenvolvimento de tecnologias era algo cumulativo e pessoal, porém com resultados coletivos. Com relação à moral, esta foi direcionada para atuação do operário como produtor e reprodutor de ações e atividades necessárias ao labor. Por fim, a dimensão social era apontada pelo fato do jornal defender uma sociedade cuja produção e riquezas fossem para o "desenvolvimento coletivo".

Portanto, não se pode pensar numa visão estritamente material e econômica acerca da temática da instrução veiculada pelo jornal. Ela faz parte de algo maior que está direcionada à proposta política do jornal e à ideia de sociedade que por ele é defendida. ${ }^{8}$

No outro sentido, a instrução colocava-se como fundamental para garantir a inserção do operário na vida política. Isto porque a Constituição de 1891, como destacou-se anteriormente, acabou estabelecendo que somente homens, brasileiros, maiores de 21 anos e alfabetizados poderiam gozar de direitos políticos.

Em estudo que buscou apontar a relação entre o movimento operário e a educação dos trabalhadores na Primeira República, Cristiane Porfírio de Oliveira do Rio trouxe informações importantes acerca dos índices de analfabetismo. Resgatando os censos de 1890 e 1900, asseverou a existência na Primeira República de 82,63\% de iletrados na população total e 69,63\% para os vinte estados (2009, p. 157). 
Dessa forma, a Constituição de 1891 acabou excluindo uma gama significativa da população brasileira - analfabetos, mulheres e menores de 21 anos - entre elas uma grande parcela de operários. Segundo José Murilo de Carvalho, na República, por volta de 2\% da população total votava $(1997$, p. 43, p. 85$)$.

Este processo assegurou aos "grupos dominantes" amplo controle do processo eleitoral.

Todo o processo eleitoral era controlado pelo partido situacionista, propiciando fraudes, e não havia voto secreto, deixando os eleitores a mercê de todo tipo de pressão. Assim, durante a Primeira República, as eleições de candidatos operários foram fenômenos raros, limitados a uns poucos casos: como o do tipógrafo João Ezequiel, eleito deputado estadual, em 1913, em Pernambuco graças a sua inclusão na lista oficial do governador general Dantas Barreto; e, em 1928, a eleição dos comunistas Minervino de Oliveira e Octávio Brandão para o Conselho Municipal do Distrito Federal pelo Bloco Operário e Camponês. As características do funcionamento dos legislativos, com garantia de ampla maioria para o situacionismo, tornavam as eleições de eventuais candidatos muito mais um feito propagandístico do que uma possibilidade para mudanças significativas no sistema político (BATALHA, 2003, p. 180-181).

Em Manaus, os documentos pesquisados não evidenciaram, para o período da Primeira República, operários amazonenses ocupando cadeiras no parlamento estadual ou no conselho municipal. Visando a mudanças neste quadro, a instrução era encorada como essencial para a participação do operário no processo político-eleitoral. Portanto, uma vez estabelecida e defendida a luta parlamentar, a instrução, nesse sentido, tornava-se necessária.

Também não faltará quem deseje ser apresentado pelas classes operárias, porque terão plena certeza, que ela estará daqui a um certo tempo inteiramente poderosa, conquistando assim os seus verdadeiros ideais. 
O jornal vida operária e a instrução educacional...

E por essa razão, concitamos aos nossos companheiros ainda não instruídos, que procurem as escolas a fim de se alimentarem com o verdadeiro pão espiritual da instrução! O mundo caros companheiros, só se acaba é para quem morre. Não perdemos, portanto as esperanças da vitória, a qual um dia será nossa (VIDA OPERÁRIA, nº 16. Manaus, 30 de maio de 1920).

Em virtude disso, o jornal apoiava projetos que buscavam implantar a instrução, inclusive no interior das associações (União Operária, Associação dos Construtores Civis e outras ligadas ao jornal), procurando incentivar a sua viabilização, mesmo com as constantes dificuldades de ordem econômica e política presentes neste momento. A ideia era qualificar o operário para a participação ativa no processo político-eleitoral da Primeira República brasileira.

Este processo não era algo isolado, pelo contrário, estava presente em diversas regiões do Brasil, intensificando-se na década de 1910, ganhando inclusive espaço em discursos oficiais, como ocorreu numa declaração de Nilo Peçanha no processo de campanha presidencial em 1921-1922. Segundo Ferreira e Pinto:

O destaque dado à questão da relação Capital/Trabalho estava ligado a intensa agitação operária que marcou os últimos anos da década de 1910 e colocou em evidência o debate acerca da questão social. Nilo advogava igualmente a extensão da instrução pública para acabar com o analfabetismo e como alternativa para ampliar a participação política dos segmentos desprivilegiados (2006, p. 7-8).

Interessante observar que a demanda operária foi identificada e apropriada em discurso na campanha presidencial de Nilo Peçanha em 1921. Assim, evidenciou-se a importância dada à instrução pelo jornal Vida Operária, como instrumento de inserção política do operário.

Porém, enquanto buscava viabilizar a instrução, o jornal procurava pessoas que haviam se candidatado para, por meio do voto e da eleição, colocá-las nos espaços formais de decisão política, para que 
pudessem defender as demandas operárias. ${ }^{9}$ Pode-se notar esta postura nos artigos publicados pelo Vida Operária sobre a sucessão governamental que ocorreu no dia quatorze de julho de 1920, no Amazonas.

Antes dessa data, especialmente no dia quatro de abril de 1920, o jornal passou a veicular uma série de artigos sobre a sucessão. Neste espaço de tempo - entre quatro de abril e quatorze de julho - esses artigos publicados em doze números consecutivos tinham por objetivo explicitar posições e opiniões a respeito do tema, destacando a importância de eleger representantes que estivessem compromissados com a causa operária.

Por outro lado, a posição do jornal era contundente na condenação daqueles que se distanciassem dessa causa.

\section{Alerta operários!}

Ribomba os horizontes políticos, pesada trovoada; cruzam na imensa órbita da politicalha, relâmpagos de opiniões; o infinito espaço, enegrece-se de candidaturas e, copiosa chuva de promessas, ameaça cair sobre o infeliz povo do Amazonas! Operários não vos assusteis!

São eles, sempre eles, de todas as épocas, de todos os tempos! Sim! São eles, que aí vem com as suas promessas legendárias! Todos eles, apresentando-se com direitos adquiridos pelos serviços prestados, mas, - todos esses serviços, estão plenamente comprovados, que não foram para o povo!...

Milhões de promessas, grandes empreendimentos, colossais problemas, enormes melhoramentos [...] passadas as eleições? Todos esses castelos não passaram nem passarão de confeccionados estratagemas preparados, para serem lançados ao povo.

\section{$[\ldots]$}

Uma vez reconhecidos e empoleirados, afirmam que sua vitória, dependeu exclusivamente do prestígio de seu partido, depois desconhecem o eleitorado, renegam os amigos, traem a sua própria política, e acabam fazendo do erário público balcão de negociatas. 
O jornal vida operária e a instrução educacional...

Diante de todos esses factos, nós operários [...], o único eleitor, poderemos assistir passivos a todas essas farsas lançadas sobre nós, sem o menor protesto?

Não! Mil vezes não!

Deveremos compenetrados nas nossas forças, nos nossos direitos, repelir todos aqueles que, pelos seus atos tenham demonstrado o quilate de seu caráter.

Devemos reagir moralmente com todo o furor de nossa dor, esses vendilhões banais, que vendem o seu caráter, e tentam subjugar o nosso e o nosso trabalho... (VIDA OPERÁRIA, $\mathrm{n}^{\circ}$ 10. Manaus, 11 de abril de 1920).

O instrumento capaz de repelir aqueles que marginalizavam as demandas do operário era o voto. O voto era a operacionalização ao mesmo tempo do protesto e da renovação e mudança. Por meio deste instrumento, o operário poderia retirar ou inserir candidatos na cadeira governamental ou no parlamento. Nesta esteira, o jornal alertava para a importância do debate e da discussão, no seio das sociedades operárias, de nomes que se alinhavam com a causa operária.

De dezenas de nomes apresentados a sucessão governamental, apresentam-se três que se destacam por ser de correntes opostas. Não queremos hostilizar este ou aquele, porém orientamos ao Povo principalmente ao operariado em geral que devemos cerrar fileiras ao lado daquele que consultar os interesses do povo.

Devemos trabalhar com todas as nossas forças ao lado daquele que nos garanta a queda do patronato e a regulamentação entre o Capital e o Trabalho, por que são as aspirações dos nossos ideais, e será um passo agigantado que daremos na evolução da nossa vida associativa.

$[\ldots]$

Avante operários!

$[\ldots]$

É chegado o momento das nossas reivindicações!

Cada operário deve correr as urnas sufragando um nome... (VIDA OPERÁRIA, nº 17. Manaus, 06 de junho de 1920). 
Cabe colocar em relevo que a eleição e o voto eram considerados como essenciais, o que também explica o direcionamento do jornal, nesse processo de sucessão governamental, para além dos operários, dirigindo-se ao povo em geral.

Parece que o jornal Vida Operária acabou promovendo uma articulação do jornal e da parcela que ele representava, no interior do processo político-eleitoral (sucessão governamental de 1920), com os setores da oligarquia regional e seus mecanismos de inserção nos espaços políticos formais.

Enfim, o jornal Vida Operária defendia três elementos como suporte da luta operária por direitos políticos e sociais: a associação, o partido e o próprio jornal. Não negava o regime republicano (mas sim a forma como estava sendo conduzido), não negava o processo político-eleitoral (mas sim o sistema que vigorava e que excluía uma parcela significativa de operários e populares) e aceitava a colaboração entre as classes. Para isso, lutava pela inserção do operariado, via instrução, no sistema político-eleitoral da Primeira República brasileira.

\section{Considerações finais}

Como procuramos evidenciar, o jornal Vida Operária surgiu na arena jornalística amazonense, em 1920, como um veículo de mobilização, conscientização e luta direcionado aos operários. Nele artigos e notícias sobre o universo operário - denúncias sobre questões do trabalho e da carestia de vida, situação política do operariado amazonense, ação operária a ser desenvolvida, importância de um partido operário e outros - foram divulgados.

Com efeito, o jornal Vida Operária propagou a defesa de uma proposta de ação política operária dentro do sistema político estabelecido no interior da Primeira República brasileira. Esta proposta consistia na participação do operariado no processo político-eleitoral como eleitores e candidatos, para que pudessem, no interior de um Partido Operário, criar condições para que as reformas sociais, sobretudo relacionadas ao mundo do trabalho, fossem realizadas pela via parlamentar, por meio de uma legislação voltada para o trabalho especialmente. 
Neste processo, a instrução era vista como algo essencial, um instrumento de inserção política do operário no cenário político da Primeira República. Isto porque na Primeira República analfabetos não podiam votar e ser votados. Por força disso, a atuação no sentido de promover a instrução educacional era defendida como ponto importante da ação política operária no Amazonas.

\section{THE NEWSPAPER LIFE WORKER}

\section{AND EDUCATION AS A TOOL OF INTEGRATION POLICY}

Abstract: The present paper aims to demonstrate, through the content of the press working in the Amazon, as the newspaper Life Worker position was the political process in the current electoral First Brazilian Republic, highlighting the critical, the proposed action labor politics and emphasis on education (education, where reading and writing, especially) as a tool for political participation. Keywords: First Republic. Life Worker Journal. Instruction Educational. Political Electoral Process.

\section{Notas}

${ }^{1} O$ Gutemberg foi o primeiro jornal operário a circular na arena jornalística amazonense, em quinze de novembro 1891, tendo como subtítulo Periódico Noticioso e Literário e como divisa "um por todos e todos por um". Sua oficina e redação funcionavam na praça cinco de setembro $\mathrm{n}^{\circ} 42$. Com o formato de $41 \times 29 \mathrm{~cm}$, foram editados 25 números, dos quais apenas três ( $\mathrm{n}^{\circ}$ 01, 19 e 25) encontram-se microfilmados em arquivos localizados no Estado do Amazonas (Biblioteca Pública, Museu Amazônico IGHA e LHIA). Este periódico era vendido avulso por sessenta réis e por assinaturas trimestrais ao preço de $3 \$ 000$, para a capital, e $4 \$ 000$ para o interior. Interessante destacar que no seu primeiro título o jornal trazia o recado de que a venda só se daria avulsa e não por assinaturas. Ao que parece, houve dificuldades no que tange à venda avulsa, sendo aceita e oferecida a venda por assinaturas. Possuía quatro páginas e três colunas. Nos títulos de $\mathrm{n}^{\circ} 01$ e $\mathrm{n}^{\circ} 19$, as páginas eram preenchidas basicamente com matérias e informações, não havendo imagens nem anúncios e propagandas. Quanto a estes últimos, só vão aparecer na última página do $\mathrm{n}^{\mathrm{o}} 29$ do periódico e sem imagens, somente texto. Como estava ligado à classe dos tipógrafos, a distribuição para esta categoria era gratuita, assim como também espaços na coluna do jornal para a defesa de seus direitos políticos e sociais. Segundo o próprio jornal, as estações de venda localizavam-se nas tabacarias 22, no mercado público e por todos os círculos da cidade. Quanto à tiragem, no 
primeiro número, o jornal indica a cifra de 1.000 exemplares publicados. O corpo de redação era composto por Francisco Alves Medeiros, Izidoro Vieira, V. Galvão, R. Vasconcellos, Ântônio Leão e Marcellino da Exaltação Fernandes.

${ }^{2}$ Elaboração de alianças entre as oligarquias que conduziam à política em nível federal com as que conduziam em nível estadual e municipal (Política dos Governadores). ${ }^{3}$ Gutenberg (1891-1892), Operário (1892), Tribuna do Caixeiro (1908-1909), Confederação do Trabalho (1909), O Marítimo (1911), Recordação (1911), Marinha Mercante (1913), A Luta Social (1914), Folha Marítima (1916), O Construtor Civil (1920), O Extremo Norte (1920), Vida Operária (1920) e O Primeiro de Maio (1928).

${ }^{4}$ Não somente Manaus, mas Belém, capital do estado do Pará, também tornou-se centro comercial do produto, que era escoado pelas duas cidades.

${ }^{5}$ Sistema de adiantamento de mercadorias a crédito. Começou a ser utilizado na região amazônica na época colonial, consolidando-se no período da economia gomífera. Por ele, as casas aviadoras forneciam mercadorias a crédito para os seringalistas, que forneciam a crédito para os seringueiros. Este processo produziu uma espécie de cadeia de créditos.

${ }^{6}$ Nesse sentido, é definido como Imprensa Operária por se direcionar à classe trabalhadora, contemplando temas e questões do universo operário (FERREIRA, 1988). ${ }^{7}$ Problemas de vigilância e controle do pleito pelos situacionistas, de compra e venda de votos - chamada pelo jornal de "agiotagem do voto" -, corrupção etc. ${ }^{8} \mathrm{O}$ jornal seguia a linha do Socialismo Reformista.

${ }^{9}$ Isto ficou visível quando, em artigos específicos, o jornal passou explicitamente a apoiar candidatos ligados à oligarquia amazonense, em que pese à cobrança por maior atenção ao operariado.

\section{Referências}

BATALHA, Cláudio. Formação da Classe Operária e Projetos de Identidade Coletiva. IN: FERREIRA, Jorge; DELGADO, Lucilia de Almeida Neves (Org.). O Brasil Republicano. Vol 1. Rio de Janeiro: Civilização Brasileira, 2003.

Editor, 2000.

O Movimento Operário na Primeira República. Rio de Janeiro: Jorge Zahar

CAPELATO, Maria Helena Rolim. Imprensa e História do Brasil. 2. ed. São Paulo: Contexto/Edusp, 1994.

CARVALHO, José Murilo de. Os Bestializados: o Rio de Janeiro e a República que não foi. São Paulo: Companhia das Letras, 1987.

CASTELLUCCI, Aldrin Armstrong Silva. Trabalhadores, máquina politica e eleições na Primeira República. Tese (Doutorado). Universidade Federal da Bahia, 2008.

Anos 90, Porto Alegre, v. 21, n. 39, p. 311-336, jul. 2014 
COSTA, Francisca Deusa Sena da. Quando o Viver Ameaça a Ordem Urbana. Dissertação (Mestrado em História). São Paulo: PUC, 1997.

DIAS, Edinéia Mascarenhas. A Ilusão do Fausto - Manaus (1890-1920). Manaus: Valer, 1999.

FERREIRA, Maria de Nazareth. Imprensa Operária no Brasil. São Paulo: Ática, 1988. FERREIRA, Marieta de Moraes; PINTO, Surama Conde Sá. A Crise dos anos 20 e a Revolução de Trinta. Rio de Janeiro: CPDOC, 2006. $26 \mathrm{f}$.

GOMES, Ângela de Castro. A Invenção do Trabalhismo. São Paulo: Vértice, 1988. GONÇALVES, Adelaide (Org.). Ceará Socialista - Anno 1919. Florianópolis: Insular, 2001.

PÁDUA, J. A. Valladares. A Capital, a República e o Sonho: a experiência dos partidos operários de 1890. Dados - Revista de Ciências Sociais. Rio de Janeiro: IUPERJ, v. 28, no 2, 1985. p. 163-192.

PETERSEN, Sílvia Regina Ferraz. Que a união operária seja a nossa pátria!: história das lutas dos operários gaúchos para construir suas organizações. Santa Maria: Editora da UFSM; Porto Alegre: Editora da UFRGS, p. 55-134, 2001.

PINHEIRO, Maria Luiza Ugarte. A Cidade Sobre os Ombros: Trabalho e Conflito no Porto de Manaus (1899-1925). Manaus: Edua, 1999.

RIO, Cristiane Porfírio de Oliveira do. O movimento operário e a educação dos trabalhadores na Primeira República: a defesa do conhecimento contra as trevas da ignorância. Tese (Doutorado). Universidade Federal do Ceará, 2009.

SANTOS, Eloína Monteiro dos. A rebelião de 1924 em Manaus. 3. ed. Manaus: Valer, 2001.

SANTOS, Roberto. História Econômica da Amazônia (1800/1920). São Paulo: T.A. Queiroz, 1980.

TELES, Luciano Everton Costa. O jornal Vida Operária: instrumento de conscientização, mobilização e luta dos trabalhadores de Manaus. Diálogos, vol. 15, n. 3, set./dez., p. 611-630, 2011.

WEINSTEIN, Bárbara. A borracha na Amazônia: expansão e decadência (18501920). São Paulo: HUCITEC, 1993.

ZICMAN, Reneé Barata. História Através da Imprensa: algumas considerações metodológicas. Projeto História, n. 4. São Paulo: Educ, p. 89-102, 1985.

Recebido em: 27/12/2012.

Aprovado em: 01/10/2013. 